\title{
MARK4 wt Allele
}

National Cancer Institute

\section{Source}

National Cancer Institute. MARK4 wt Allele. NCI Thesaurus. Code C114392.

Human MARK4 wild-type allele is located in the vicinity of 19q13.3 and is approximately $226 \mathrm{~kb}$ in length. This allele, which encodes MAP/microtubule affinity-regulating kinase 4 protein, is involved in the phosphorylation of microtubule-associated proteins. Aberrant overexpression of the gene is associated with hepatocellular carcinoma. 